\title{
Designing Rice Dryer with A Capacity Of 1000 Kg / Hour Using Rice Husk Heater
}

\author{
Agung Sutrisno ${ }^{1, ~ a ~}$ \\ 'Sam Ratulangi University Basic Research Grant 2020Bahu, Malalayang, Manado City, \\ North Sulawesi, Indonesia \\ aagungsutrisno@unsrat.ac.id
}

\begin{abstract}
Abstrak.
Salah satu cara dalam mengolah hasil pertanian adalah dengan proses pengeringan. Merupakan proses penurunan kadar air sampai batas tertentu sehingga dapat menghambat laju kerusakan hasil pertanian (beras) akibat aktivitas biologi dan kimiawi. Pengeringan adalah langkah terakhir dalam rangkaian operasi, dan produk pengeringan biasanya siap digunakan. Tujuan dari penelitian ini adalah merancang Mesin Pengering Padi berkapasitas $1000 \mathrm{Kg}$. Hasil penelitian menunjukkan spesifikasi desain pengering.
\end{abstract}

Kata kunci. Pengering baki, Padi, Pengeringan

\begin{abstract}
.
One way of processing agricultural products is by drying process. It is a process of reducing water content to a certain extent so that it can inhibit the rate of damage to agricultural products (rice) due to biological and chemical activities. Drying is the last step in a series of operations, and the drying product is usually ready to use. The goal of this research is to design Paddy Drier with $1000 \mathrm{Kg}$ capacity. The result of the study showing the design specification of the drier..
\end{abstract}

Keywords: Tray dryer, Paddy, Drying

\section{INTRODUCTION}

In Indonesia, the weather is uncertain, there are often changes that are not known at any time. The rainy season makes it difficult for farmers to dry their crops. Therefore it is necessary to make a dryer to secure their crops.

Drying is a process of reducing the moisture content of the harvested product, if it still contains moisture, the product may rot. The moisture content of agricultural materials is usually expressed in percentage of wet basis and percentage of dry basis.

Drying is usually divided into two parts, namely sun drying and artificial drying. Sun drying requires sunlight as an energy source, heat source and ultraviolet light. This drying is done openly, sometimes there is a big gust of wind from the air so that drying is slow and is also prone to contamination from the air, and dust from the surrounding environment. In addition, this drying is carried out only when the weather permits. If not, you can also use artificial drying. Artificial drying using fuel. The working principle is heating by conduction (heat delivery) or convection (heat transfer) which aims to reduce the moisture content of food.

After the rice drying is complete, the milling process is carried out. This engine will produce components such as rice and husks, while rice husks have been disposed of as services and require a large disposal location.

From the description above, the authors are interested in carrying out research to make a drying device with a capacity of one ton $(1000 \mathrm{~kg} /$ hour $)$ using rice husk heaters.

\section{LITERATURE REVIEW}

\subsection{Overview of Drying}


Drying is the process of removing volatile substances (water content) from solids. The general purpose of drying is to reduce the moisture content of the dried product. The process carried out is by increasing the partial pressure of water vapor in the material by providing heat and increasing the relative humidity of the drying air. The ability of air to carry water vapor increases if the difference in partial pressure of water vapor in the drying air and the material being dried is greater. Basically the drying process is done in two ways, are as follows: Natural Drying and Artificial Drying.

\subsection{Introduction to Drying}

Heat transfer is one of the disciplines of thermal engineering that studies how to generate heat, use heat, convert heat, and exchange heat between physical systems.

The basic forms of heat transfer are:

- Conduction or diffusion

- Convection

- Radiation

\subsection{Tray Dryer}

A room consisting of a chamber containing a drying rack. Each shelf has a number of shallow trays with a thickness of $10-100 \mathrm{~mm}$ which are full of material to be dried. The circulated hot air has a speed of between $7-15 \mathrm{ft} / \mathrm{s}$ between the tray with the help of a fan and a motor, flowing through the heater. The bulkhead serves to direct the flow of air uniformly over the tray arrangement. Some of the wet air is ventilated through the feeder. The racks are arranged on top of racks with wheels attached to the bottom so that at the end of the drying cycle the racks can be pulled out of the drying chamber. This dryer can be used for a variety of materials. Sometimes through circulation is used for energy saving, otherwise the tray dryer can operate in a vacuum.

\subsection{Paddy Drier}

Rice plants are plants that are classified as water planting. As an aquatic plant, it does not mean that rice plants can only grow on land which is continuously flooded. Rice plants can also grow on land or dry land, as long as the rainfall is sufficient for the plants' need for water.

Harvesting is an activity that must be done at the right time, because the level of seed maturity affects yield, quality and yield loss. The right time to harvest rice is 33-36 days after the rice flowering evenly. While the harvest is done before it is ripe, the ripe yield will result in shrinkage of the yield, and vice versa if it is harvested late then the yield will decrease (rice yield will become cracked).

The drying process occurs because of the evaporation of water into the air, this is due to the difference in the moisture content between the air and the material to be dried. This method is done by reducing the humidity of the air by circulating heat around the material. The objectives of grain drying are as follows:

1. Reducing the moisture content of the grain to a limit where the development of microorganisms and enzyme activities that can cause decay is inhibited or stopped or to maintain the viability of the grain.

\section{5 Drying Performance}

\subsubsection{Air Water Content}

The water content of the material shows the amount of water per weight of the material. In determining the water content, the following equations are used:

1. Determining water content based on wet weighting: $X a=\frac{W a}{W b} .100 \%$

Where: $\quad \mathrm{Xa}=$ Water connet wet weight $(\%)$

$\mathrm{Wa}=$ water weight $(\mathrm{kg})$

$\mathrm{Wb}=$ net weight of material $(\mathrm{kg})$

2. Determination of water content based on dry weight : $X b=\frac{W a}{W k} \cdot 100 \%$ 
where: $\quad \mathrm{Xb}=$ net dry weight $(\%)$

$\mathrm{Wa}=$ wet material weight $(\mathrm{kg})$

$\mathrm{Wk}=$ weight of dried material $(\mathrm{kg})$

\subsection{2, Material Equilibrium}

What is meant by material equilibrium is the balance between the weight of incoming unhulled rice and the sum of the resulting weight of dried grain with evaporated water. To calculate the material equilibrium, you must first know:

1. Weight of paddy water intake

$\mathrm{Wa}=\mathrm{Wb} . \mathrm{Xb}$

2. Weight of paddy water outake

$\mathrm{Wk}=\mathrm{Wb} .(100 \%-\mathrm{Xb})$

3. Weight of vaporated water

$\mathrm{W}=\mathrm{Wa}-\mathrm{Wk} \quad(\mathrm{kg})$

Therefore, the material equilibrium becomes:

Weight of wet paddy intake $=$ net weight of wet paddy+ Weight of vaporated water

A. In determining the temperature of the drying air, there are several things that need to be known first, namely:

1. air volume needed to dry $\mathrm{V}=\mathrm{F} . \mathrm{v} .3600 \quad\left(\mathrm{~m}^{3} / \mathrm{hr}\right)$

where: $\quad \mathrm{F}=$ space of the drying area

$\mathrm{L}=$ length of the pan

$\mathrm{T}=$ height of the drier

$\mathrm{v}=$ air velocity

2. Air energy water equilibrium.

where: $\quad m_{u d}=$ mass of air drier $(\mathrm{kg})$

$$
\begin{gathered}
\text { Q air }=\text { Q paddy } \\
m_{u d} c p_{u d \cdot} \cdot\left(T_{h i}-T_{h a}\right)=m_{g} c p_{g} \cdot\left(T_{g m}-T_{g k}\right)
\end{gathered}
$$

$m_{g}=$ paddy mass $(\mathrm{kg})$

$c p_{u d}=$ air heat specific $(\mathrm{KJ} / \mathrm{kg} \mathrm{K})$

$c p_{g}=$ paddy heat specific $(\mathrm{KJ} / \mathrm{kg} \mathrm{K})$

$T_{h i}=$ intake air drier temperature $(\mathrm{K})$

$T_{h a}=$ outake air temperature $(\mathrm{K})$

$T_{g m}=$ intake paddy temperature $(\mathrm{K})$

$T_{g k}=$ outake paddy temperature

3. Determining vapour temperature $N t=\frac{T h i-T h 0}{\Delta T}$

4. Determining the amount of air heater to heat paddy

$\frac{q}{m s}=\operatorname{cpg}(T g k-T g m)+X a \cdot C p a(T w-T g m)+(X a-X b) \lambda+X b C p a(T g k-T w)+C p u(X a-$ $X b)(T h o-T w)$

where: $\quad C p g=$ Panas jenis gabah paddy heat specific $(\mathrm{KJ} / \mathrm{kg} \mathrm{K})$

$C p a=$ water heat specific $(\mathrm{KJ} / \mathrm{kg} \mathrm{K})$

$C p u=$ vapour heat $\operatorname{specific}(\mathrm{KJ} / \mathrm{kg} \mathrm{K})$

$T g k=$ outake paddy temperature $(\mathrm{K})$

Tgm $=$ vapour temperature $(\mathrm{K})$

$X a=$ water intake $(\mathrm{K})$

$X b=$ outake paddy water content $(\%)$

$\lambda \quad=$ vapour heat $(\mathrm{KJ} / \mathrm{kg} \mathrm{K})$

5. Determining the amount of water needed for vapourization: $\mathrm{Ql}=$ water mass.$\lambda$

where $\lambda=$ vapour heat

6. Heat losses calculation 
a. Wall heat absorbance : $q d=\frac{T h i-T \infty}{\frac{1}{h i}+\frac{L b}{k b \cdot A}+\frac{L p}{k p \cdot A}+\frac{1}{h o}}$

Where:Thi $=$ Intake air temperature $(\mathrm{K})$

$T \infty=$ temperature udara luar outake air temperature $(\mathrm{K})$

hi $=$ drier heat transfer coefficient

ho $=$ drier our heat transfer coefficient

$\mathrm{Lb}=$ wall width $(\mathrm{m})$

Lp = wall height $(\mathrm{m})$

$\mathrm{kb}=$ wall thermal conductivity

$\mathrm{kp}=$ mortar thermal conductivity

b. Rack heat absorbance

$\mathrm{Qr}=\mathrm{Un} . \mathrm{A} .(\mathrm{Th}-T \infty)$

$U r=\frac{1}{\frac{1}{h i}+\frac{z r}{k r \cdot A}}$

where: $\mathrm{zr}=$ rack thickness $(\mathrm{m})$

$\mathrm{kr}=$ rack thermal conductivity

$\mathrm{A}=$ rack wide $\left(\mathrm{m}^{2}\right)$

c. Pan heat absorbance

$\mathrm{Qn}=\mathrm{Un}$. A . (Thi $-T \infty)$

$\mathrm{Un}=\frac{1}{\frac{1}{h i}+\frac{z r}{k r \cdot A}}$

Where: $\mathrm{kr}=$ nampan Pan thermal conductivity

$\mathrm{A}=$ pan width $\left(\mathrm{m}^{2}\right)$

$\mathrm{Zr}=$ pan thickness $(\mathrm{m})$

\section{B. Air Drier Moisture}

Air humidity greatly affects the transfer of liquid from the grain to the outside of the grain. If the difference in vapor pressure outside the grain is small, then the displacement of the liquid flow is also small.

\subsubsection{Rate of Mass Transfer}

The mass transfer process in the drying process is the process of mass transfer of water vapor from the surface of the grain to dry hot steam in the area with the following equation:

$$
\mathrm{Mv}=m_{s} .\left(H_{a}-H_{b}\right)
$$

where: $\mathrm{m}_{\mathrm{s}}=$ mass of paddy dried (kg/hour)

$\mathrm{H}_{\mathrm{a}}=$ absolute humidity of air intake

$\mathrm{H}_{\mathrm{b}}=$ absolute humiditiy of air outake

\subsubsection{Dried air velocity}

Dry heat flow rate is the amount of dry hot air required in the drying process on the tray drayer per unit time. The dry hot air flow rate Gp can be calculated using the following equation:

$$
\mathrm{Gp}=\frac{Q \text { total }}{\text { Cpu } \cdot(\text { Thi-Tho })}
$$

where : $\mathrm{Q}$ total $=$ kalor total pengering $(\mathrm{KJ})$

$\mathrm{Cpu}=$ vapour specific heat $(\mathrm{KJ} / \mathrm{kg} . \mathrm{K})$

Thi $=$ drier air intake temperature $(\mathrm{K})$

Tho $=$ drier air intake temperature $(\mathrm{K})$

\subsection{6. air velocity}

The requirement for dry air flow to free water vapor can be calculated using the following equation: $\mathrm{V}=\frac{W}{(H a-H b)}$. Vs

where: $\mathrm{w}=$ laju perpindahan uap air vapour velocity transfer $(\mathrm{kg} / \mathrm{jam})$ 
$\mathrm{Ha}=$ Absolute air intake temperature

$\mathrm{Hb}=$ Absolute air temperature outake

$\mathrm{Vs}=$ air specific volume $\left(\mathrm{m}^{3} / \mathrm{kg}\right)$

\subsubsection{Drying Time}

In the design of the dryer, drying time is a very determining factor in a drying process. Besides that, the drying time also determines the speed of the drying process. Drying can be calculated using the following equation: $\mathrm{T}=\frac{m w}{R c \cdot A}$

where: $\mathrm{mw}=$ number of water vaporated $(\mathrm{kg})$

$\mathrm{A}=$ wide are of paddy.

\subsection{Combustion Chamber}

The combustion chamber in the dryer serves to heat the air before it enters the dryer. The heat in the combustion chamber begins with the ignition of the rice husks. The air that passes through the combustion chamber is then flowed into the drying chamber through the pipes with the help of a suction blower. It is expected that hot air will enter the drying room with a temperature of $40-45^{\circ} \mathrm{C}$ in the combustion chamber consisting of supporting parts, including fuel and blower.

\subsection{Heating Pipe}

In the dryer, pipes play an important role. Inside the pipe the fluid is high temperature, pressurized and has a viscosity. For this reason, the pipes used must be able to transfer heat or have good heat resistance. The ability to release or receive heat is also influenced by the large surface area which depends on the length, diameter and number of pipes used. The operation of the dryer in operating conditions often cannot be estimated from thermal analysis alone. Besides operating, a layer of dirt will be formed on the surface of the heat piping. This is called the fouling effect which increases the thermal resistance.

\subsection{Drier Dimensions}

2.9.1. heater area.

The maximum allowable heating air flow rate per unit of dryer area $\mathrm{G}(\mathrm{kg} /$ hour $\mathrm{m} 2)$ is the limit where at this speed the amount of material dusting in the air flow is still within the allowable limit. The allowable heating airflow rates are in the range of $200-10,000 \mathrm{lb} / \mathrm{hr}$.ft 2 . From the material and heating equilibrium as well as the conditions it is known the price of heating air flow rate ( $\mathrm{Gp}$ ). So you can find the price of the cross-sectional area, where the effective cross-sectional area of the dryer is 0.85 of the cross-sectional area of the dryer, so we get the equation: $\mathrm{A}=\frac{G p}{0,85 . G}\left(\mathrm{~m}^{2}\right)$

2.9.2. Drier Volume

tray dryer volume is calculated by $\mathrm{V}=\frac{Q \text { total }}{h a, \Delta T} \quad\left(\mathrm{~m}^{3}\right)$

Where: ha. = volumetric heat coefficient

$$
=\frac{k \cdot G s^{n}}{L}=\frac{G}{A} \quad\left(\mathrm{~kg} / \text { hour } \cdot \mathrm{m}^{2}\right)
$$

\subsection{3, Rack drier dimensions}

Tray dryer has several types of flights that can be selected according to their needs and functions. The type of flight is determined by considering the uniform gas and ingredients based on the size of the material. In planning this grain dryer using a rack plate-shaped drying media.

\subsubsection{Frame}

In planning a construction what needs to be concerned about is strength and security, in the sense that the framework must be able to withstand the existing loads. In addition, the economic value of material selection is also considered so as to reduce costs. And to determine the strength of a material, it is necessary to know the characteristics of the material. 


\section{RESEARCH METHODS}

\section{1 Research Locus}

The place where this research was carried out was in the village of Mopugad Selatan, Kec. North Dumoga Kab. Bolaang Mongondow, time of March 2020 to October 2020

\section{2 Materials and Equipments}

Space area with dimensions of $(2 \times 2 \times 2,5 \mathrm{~m})$, Combustion Chamber with dimensions $(1 \times 1 \times$ $1 \mathrm{~m})$, Galvanic pipe (2 inch), Thermometer, Stopwatch.

\section{3. Research Procedure}

This research was carried out systematically and the structure of its implementation with research prosedure as shown in figure 4.1. Explanation of the research procedure, as follows :

1. Preparation phase, at this stage it is a process for studying references related to this research.

2. Manufacture of a dryer, in this stage, the process of making a drying device with a capacity of $1000 \mathrm{~kg} /$ hour is carried out for approximately 3 months

3. Measurement Procedure, drying can only be done if the temperature is $50^{\circ} \mathrm{C}$. Calculation of research results using formulas from the existing theoretical basis. Like calculating the flow rate of hot air.

\section{RESULTS AND DISCUSSION}

\subsection{Research Data}

\subsubsection{Design Data}

To plan a rack dryer, first the data regarding the grain to be dried must be known as follows:

Paddy weight $\quad: 1000 \mathrm{~kg}$

Density $\quad: 266.65 \mathrm{~kg} / \mathrm{m}^{3}$

Water content paddy intake : $22 \%$

Water content paddy outake : $14 \%$

Drying temperature $\quad: 40^{\circ} \mathrm{c}$

Drying temperature out $\quad: 25^{\circ} \mathrm{C}=298 \mathrm{~K}$

Drying temperature in $\quad: 30^{\circ} \mathrm{C}=303 \mathrm{~K}$

Cp paddy $\quad: 0,8 \mathrm{KJ} / \mathrm{kg} \mathrm{K}$

Cp air $\quad: 1,0057 \mathrm{KJ} / \mathrm{kg} \mathrm{K}$

Air Density $\quad: 1,1774 \mathrm{~kg} / \mathrm{m}^{3}$

Wall thermal conductivity $: 0,65 \mathrm{~W} / \mathrm{m}^{2} \mathrm{~K}$

Thermal conductivity $: 202,527 \mathrm{~W} / \mathrm{m}^{2} \mathrm{~K}$

Conductivity $\quad: 16,27 \mathrm{~W} / \mathrm{m}^{2} \mathrm{~K}$

Air velocity $: 4 \mathrm{~m} / \mathrm{s}$

Heat vapour $\quad: 2,43308 \mathrm{KJ} / \mathrm{kg} \mathrm{K}$

4.1.2, Determining paddy volume L

$$
\begin{aligned}
\mathrm{V} & =\frac{m}{\rho} \\
& =\frac{1000 \mathrm{~kg}}{266,65 \mathrm{~kg} / \mathrm{m}^{3}}=3,75 \mathrm{~m}^{3}
\end{aligned}
$$

4.1.3, Determining rack dimension

Quantity of rack $=3$,

$\mathrm{P}=2 \mathrm{~m} \quad \mathrm{~L}=1 \mathrm{~m} \quad \mathrm{t}=0.1 \mathrm{~m}$

$\mathrm{V}=(2 \times 1 \times 0.1)=0,2 \mathrm{~m}^{3}$

Pan number $=\frac{3.75}{0.2}=18,75 \approx 20$

Rack height $=(0.1 \times 10)+(0.06 \times 10)=1,6 \mathrm{~m}$ 


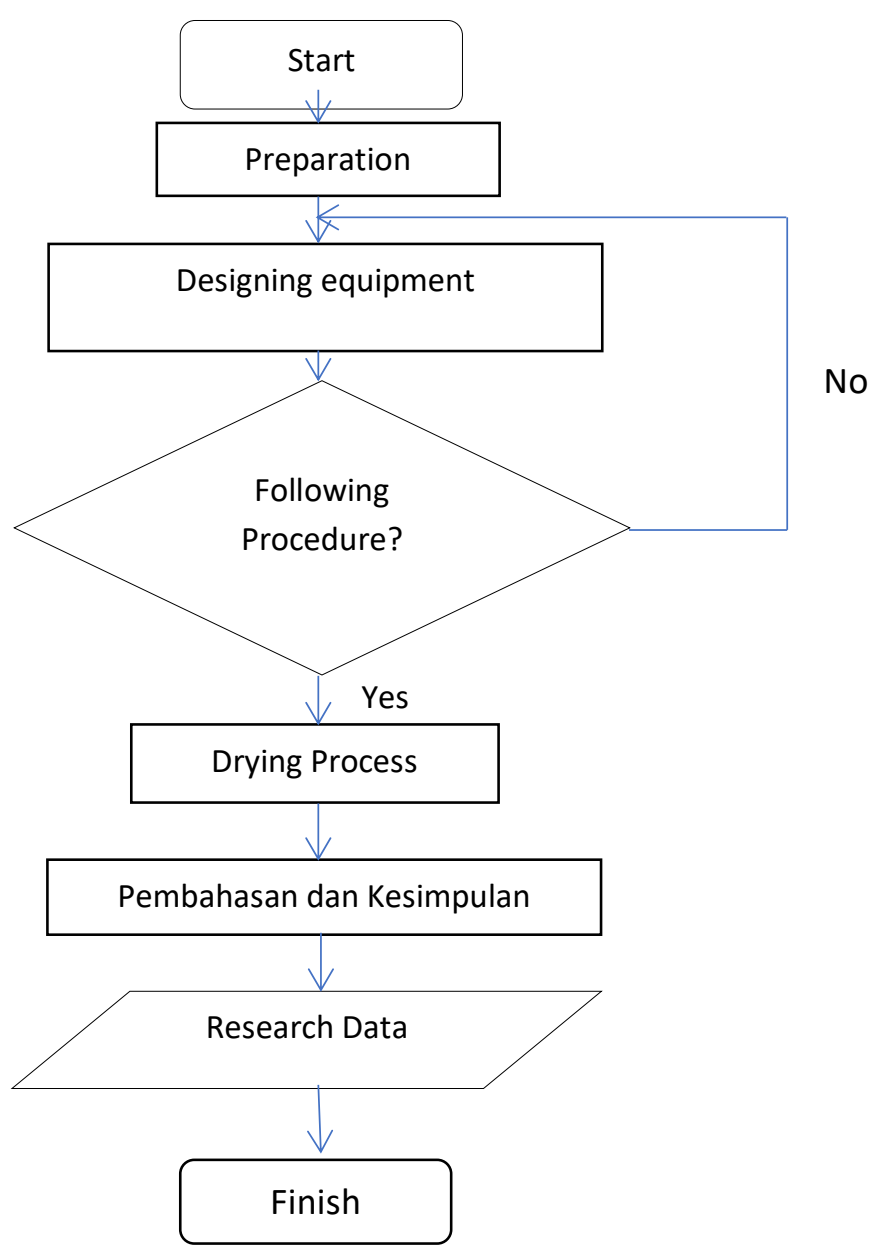

Figure 4.1 Research Procedure

4.1.4, Material balance

What is meant by material balance is the balance between the mass of incoming unhulled grain and the sum of the dry weight of the grain and the weight of water evaporated.

- Berat air dalam gabah

$\mathrm{W}_{\mathrm{mb}}=\mathrm{m}_{\mathrm{b}} . \mathrm{X}_{\mathrm{b}}=1000 \times 22 \%=220 \mathrm{~kg}$

- Berat kering gabah

$\mathrm{W}_{\mathrm{mk}}=\mathrm{m}_{\mathrm{b}}\left(100 \%-\mathrm{X}_{\mathrm{b}}\right)=1000 .(100 \%-22 \%)=780 \mathrm{~kg}$

- Berat air dalam gabah kering

$\mathrm{W}_{\mathrm{ak}}=\mathrm{W}_{\mathrm{k}} . \mathrm{X}_{\mathrm{a}}=780.0,14=109,2 \mathrm{~kg}$

- $\quad$ Berat air yang menguap

$\mathrm{M}_{\mathrm{w}}=\mathrm{W}_{\mathrm{mb}}-\mathrm{W}_{\mathrm{ak}}=220-109,2=110,8 \mathrm{~kg}$

- $\quad$ Berat gabah kering

$\mathrm{W}_{\mathrm{k}}=\mathrm{W}_{\mathrm{mk}}+\mathrm{W}_{\mathrm{ak}}=780+109,2=889,2 \mathrm{~kg}$

The material equilibrium then becomes:

Material equilibrium $=$ weight of dry paddy + weight of vapour

$$
\begin{aligned}
& =889,2+110,8 \\
& =1000 \mathrm{~kg}
\end{aligned}
$$

4.1.5. Heat Transfer rate

- To determine air volume needed to dry we can use:

$$
\begin{aligned}
\mathrm{V}=\mathrm{F} . \mathrm{v} \cdot 3600(\mathrm{~m} / \mathrm{s}) & \\
\mathrm{L} & =2,5 \cdot 3,5=7,5 \mathrm{~m} \\
\mathrm{~T} & =3 \mathrm{~m}
\end{aligned}
$$




$$
\begin{array}{ll} 
& \mathrm{X}=(3 \cdot 0,5)+(0,5 \cdot 3,5)=2,75 \mathrm{~m}^{2} \\
& \mathrm{~F}=7,5 \cdot 3+2,75=25,25 \mathrm{~m}^{2} \\
\text { therefore } & \mathrm{V}=25,25 \cdot 4=101 \mathrm{~m}^{3} \\
\text { Air mass } & =\rho \cdot \mathrm{V}=1,1774 \mathrm{~kg} / \mathrm{m}^{3} \cdot 101 \mathrm{~m}^{3} \\
& =118,917 \mathrm{~kg}
\end{array}
$$

- Energy equilibrium between paddy and air

from energy equilibrium between paddy and dry air we obtain:

$\mathrm{Q}_{\mathrm{udara}}=\mathrm{Q}_{\mathrm{gabah}}$

$m_{u d} c p_{u d} \cdot\left(T_{h i}-T_{h o}\right)=m_{g b} c p_{g b} \cdot\left(T_{g b k}-T_{g b m}\right)$

$268556,4156\left(313-\mathrm{T}_{\text {ho }}\right)=4000 \mathrm{~J}$

$\mathrm{T}_{\text {ho }}=311,98 \mathrm{~K}=312 \mathrm{~K}=39^{\circ} \mathrm{c}$

,- Average temperature difference (LMTD

$$
\begin{aligned}
\Delta \mathrm{T} / \mathrm{LMTD} & =\frac{(T h i-T c i)-(T h o-T c o)}{\ln \left(\frac{T h i-T c i}{T h o-T c o}\right)} \\
= & \frac{(313-290)-(312-303)}{\ln \left(\frac{313-298}{312-303}\right)} \\
= & 11,75
\end{aligned}
$$

,- Determine vapour temperature

$$
\begin{aligned}
& \Delta \mathrm{T}=\frac{T h i-T h o}{N t} \quad \mathrm{Nt}=\frac{T h i-T h o}{\Delta \mathrm{T}}=\frac{313-312}{11,75}=0,0851 \\
& \mathrm{Nt}=\ln \frac{T h i-T w}{T h o-T w} \mathrm{e}^{\mathrm{Nt}}=\frac{T h i-T w}{T h o-T w} \quad \mathrm{Tw}=\frac{\left(e^{N t}-T h o\right)-T h i}{e^{N t}-1}=\frac{\left(e^{0,0851}-312\right)-313}{e^{0.0851}-1}=301 \mathrm{~K}= \\
& 27,85^{\circ} \mathrm{C}
\end{aligned}
$$

,- The amount of heat needed to dry the paddy is counted as :

$$
\begin{aligned}
& \frac{q}{m}=\mathrm{C}_{\mathrm{pg}} \cdot\left(\mathrm{T}_{\mathrm{gk}}-\mathrm{T}_{\mathrm{gm}}\right)+\mathrm{X}_{\mathrm{a}} \cdot \mathrm{C}_{\mathrm{pa}}\left(\mathrm{T}_{\mathrm{w}}-\mathrm{T}_{\mathrm{gm}}\right)+\left(\mathrm{X}_{\mathrm{a}}-\mathrm{X}_{\mathrm{b}}\right) \eta+\left(\mathrm{T}_{\mathrm{gk}}-\mathrm{Tw}\right)+\mathrm{Cpu} \cdot\left(\mathrm{X}_{\mathrm{a}}-\mathrm{X}_{\mathrm{b}}\right) . \\
& \left(\mathrm{T}_{\mathrm{ho}}-\mathrm{T}_{\mathrm{w}}\right) \\
& =0,8(303-298)+0,22 \cdot 1 .(301-298)+(0,22-0,14) \cdot 2,43308+0,14 \text {. } 1 .(303- \\
& 301)+1,0057 \cdot(0,22-0,14) \cdot(312-301) \\
& =6,02 \mathrm{KJ} / \text { Hour } \\
& \mathrm{q}_{\mathrm{t}}=6,02 \mathrm{KJ} / \text { hour. } 780 \mathrm{~kg} \quad=4695,6 \mathrm{KJ} / \text { hour } \mathrm{kg}
\end{aligned}
$$

\subsubsection{Heat Losses Calculation}

1. Heat absorbed by heater wall :

$$
\begin{aligned}
\mathrm{Q}_{\mathrm{d}} & =\mathrm{h} \cdot \mathrm{A} \cdot\left(\mathrm{T}_{\mathrm{hi}}-\mathrm{T}_{\mathrm{h}} \infty\right) \\
& =\frac{\mathrm{Thi}-\mathrm{Th} \infty}{\frac{1}{h i}-\frac{L d}{k d \cdot A}+\frac{1}{h o}}
\end{aligned}
$$

It is kown that : $\mathrm{kd}=0,65 \mathrm{~W} / \mathrm{m}^{2} \mathrm{~K}$

$$
\begin{aligned}
& \rho=1.1774 \\
& \mu=1,983.10^{-5}
\end{aligned}
$$

For counting hi using equation below

where; $\operatorname{Re}=\frac{L \cdot V \cdot \rho}{\mu}=\frac{3,5 \cdot 4 \cdot 1,1774}{1,983 \cdot 10-5}$

$$
\begin{aligned}
& =4,3125 \cdot 10^{5} \\
\operatorname{Pr} & =\frac{C p \cdot \mu}{k}=\frac{1,0057 \cdot 1,983 \cdot 10^{-5}}{0,02624}=0,00076
\end{aligned}
$$

for $\operatorname{Pr}<0,1$ maka $\mathrm{Nu}=1,17(\operatorname{Re}, \operatorname{Pr})^{0,5}$

$\begin{aligned} \text { therefore hi } & =\frac{1,1774 \cdot(413250)(0,00076)^{0,5}}{3,5} \\ & =6,091 \mathrm{~W} / \mathrm{m}^{2} \mathrm{~K}\end{aligned}$

For counting ho is also the same as hi at $\operatorname{Re}=1557,82$ dan $\operatorname{Pr}=0,00067$ it was assumed that the heat is 
$8 \mathrm{~m} / \mathrm{s}$, therefore ho is counted as :

$$
\begin{aligned}
\text { ho } & =\frac{1,1774 \cdot(15571,82)(0,00076)^{0,5}}{3,5} \cdot 0,02227 \\
& =1,086 \mathrm{~W} / \mathrm{m}^{2} \mathrm{~K}
\end{aligned}
$$

Heat absorbed is then

$$
\begin{aligned}
\mathrm{Q}_{\mathrm{d}} & =\frac{313-3000}{\frac{1}{6,091}+\frac{0,17}{0,69.19,5}+\frac{1}{1,086}} \\
& =4,1185 \mathrm{~W} / \mathrm{m}^{2} \mathrm{~K}
\end{aligned}
$$

2. Heat absorbed by pan is counted as

$\mathrm{Q}_{\mathrm{n}}=\mathrm{Un}$. An $(\mathrm{Thi}-\mathrm{Tdn})$

$\mathrm{Un}=\frac{1}{\frac{1}{h i}+\frac{Z m}{k m}}$

$\mathrm{Un}=\frac{1}{\frac{1}{2,76}+\frac{0,002}{202,527}}=3,1496 \mathrm{~W} / \mathrm{m}^{2} \mathrm{~K}$

Equation to count the above pan temperature is:

$$
\begin{aligned}
& \mathrm{Cp}\left(\mathrm{T}_{1}-\mathrm{T}_{2}\right)=\frac{V^{2}}{2 \cdot g c} \\
& 1005,7\left(313-\mathrm{T}_{2}\right)=\frac{4^{2}}{2.1} \\
& 1005,7, \mathrm{~T} 2=341776,1 \\
& \mathrm{~T} 2=312,89 \mathrm{~K}=39,89^{\circ} \mathrm{c}
\end{aligned}
$$

Heat absorbed is then:

$$
\begin{aligned}
\mathrm{Qn} & =2,760.104 .(313-312,89) \\
& =32,42 \mathrm{~W} / \mathrm{m}^{2} \mathrm{~K}
\end{aligned}
$$

3. Pan absorbed:

$$
\begin{aligned}
\mathrm{Qr} & =\mathrm{Uk} \ldots \mathrm{A} \cdot\left(\mathrm{T}_{\mathrm{hi}}-\mathrm{T}_{2}\right) \\
& =\frac{1}{\frac{1}{h i}+\frac{z r}{k r}} \cdot \mathrm{A} \cdot\left(\mathrm{T}_{\mathrm{hi}}-\mathrm{T}_{2}\right) \\
\mathrm{qr} & =\frac{1}{\frac{1}{3,149}+\frac{0,003}{16,27}} \cdot 25,4 \cdot(313-312,89) \\
& =8,79 \mathrm{~W} / \mathrm{m}^{2} \mathrm{~K}
\end{aligned}
$$

Amount heat losses is then

$$
\begin{aligned}
\mathrm{q}_{\text {loss }} & =\mathrm{q}_{\mathrm{d}}+\mathrm{q}_{\mathrm{n}}+\mathrm{q}_{\mathrm{r}} \\
& =4,1185+32,42+8,79 \\
& =44,98 \mathrm{~W} / \mathrm{m}^{2} \mathrm{~K} \\
& =8,37 \mathrm{KJ} / \mathrm{m}^{2} \mathrm{~K}
\end{aligned}
$$

4. Total Heating Load

$$
\begin{aligned}
\mathrm{Q}_{\text {total }} & =\mathrm{Q}_{\mathrm{p}}+\mathrm{Q}_{\text {loss }} \\
& =4695,6+8,37=4703,97 \mathrm{KJ} / \mathrm{jam}
\end{aligned}
$$

\subsubsection{Drying Time}

To predict the rate of evaporation, the heat transfer coefficient must be known. For the case where the air flow parallel to the surface of the material becomes turbulent, the equation below can be used at temperatures of $45-105 \mathrm{oC}$ and mass flow velocity of dry air G between 2,450-29,300 kg $/ \mathrm{m}^{2}$ hour.

$$
\begin{aligned}
\mathrm{H} & =0,0204 \mathrm{G}^{0,8} \\
& =0,0204 .(15901,92)^{0,8} \quad=46,8586 \mathrm{~W} / \mathrm{m}^{2} \mathrm{~K}
\end{aligned}
$$

Evaporation rate:

$\mathrm{Rc} \mathrm{H}_{2} \mathrm{O} / \mathrm{h} \mathrm{m}^{2}=\frac{h}{\lambda_{u} \cdot 1000}\left(T_{h i}-T_{\mathrm{w}}\right) \cdot 3600$ 


$$
=\frac{46,8586}{2433,08 \cdot 1000}(40-27,85) \cdot 3600=0,8243 \mathrm{~kg} \mathrm{H}_{2} \mathrm{O} / \mathrm{h} \mathrm{m}^{2}
$$

Drying surface

$$
\begin{array}{rlrl}
\mathrm{A} & =(2.1) .20 \text { pan } & =40 \mathrm{~m}^{2} \\
\mathrm{mv} & =\text { Rc. } \mathrm{A} & & \\
& =0,8243.40 & =32,972 \mathrm{~kg} / \text { hour }
\end{array}
$$

Drying time:

$$
\begin{aligned}
\mathrm{T} & =\frac{\text { Amount paddy moisted }}{m v} \\
& =\frac{110,8}{32,972} \quad=3,36 \text { hours }
\end{aligned}
$$

\subsubsection{Combustion Chamber}

The furnace / combustion chamber is 1 meter high, 1 meter wide and 1 meter long

\subsubsection{Blower}

From the required hot air flow rate (for blower selection), it is known that $\mathrm{v}=26733,615 \mathrm{~m}^{3}$ /hour $=445,5602 \mathrm{~m}^{3}$ /hour, from the table a blower with a fan size 222 dimensions $23^{5 / 8}$ in is selected, $23^{5 / 8}$ outside diameter 8 in, wheel diameter $22^{1 / 4}$ in, 222 rotation angle and 45,5 HP blower.

\subsubsection{Heater Pipe}

Air is heated from $25 \mathrm{oC}$ to $40 \mathrm{oC}$ flowing in the pipe. The gas passes through the pipe beam with a temperature of 739.64o c. Galvanized pipes with an outer diameter of 2 inches are used, it is assumed that the temperature of the outer surface of the pipe is the same as the steam temperature of $739.64{ }^{\circ} \mathrm{C}$. The number of pipes is 30 pieces. From the calculation of the design of the tray dryer, there are two main results of the calculation, namely:

1. Drying performance

Factors affecting paddy drying performance

- Moisture Temperature $27,85^{\circ} \mathrm{c}$

- Quantity of Drying energy 4703,97 KJ/hour

- Air moisture $0,0379 \mathrm{~kg}$ water $/ \mathrm{kg}$ air

- $\quad$ air drier mass 4426,22 kg/jam

- Drying time 3,36 jam

- Fuel consumption $76,60 \mathrm{~kg}$

2. Dryer Dimensions

From the description above, the dimensions and sizes of the dryer are obtained as shown in table 5.1 below

Tabel 5.1 Dimensions of Paddy Drying with $1000 \mathrm{Kg}$ Capacity

\begin{tabular}{|c|l|c|c|c|c|c|}
\hline \multirow{2}{*}{ No } & \multirow{2}{*}{ Drier Components } & \multicolumn{5}{|c|}{ Dimension } \\
\cline { 3 - 7 } & & Length $(\mathrm{m})$ & Width $(\mathrm{m})$ & Height $(\mathrm{m})$ & Diameter (in) & Quantity \\
\hline 1 & Drying Chamber & 2,5 & 2,5 & 3 & - & 1 \\
\hline 2 & Drying Pan & 2 & 1 & 0.1 & - & 20 \\
\hline 3 & Drying Rack & 2,1 & 1,1 & 1,6 & - & 2 \\
\hline 4 & $\begin{array}{l}\text { Pipa Galvanis } \\
\text { Galvanic Pipe }\end{array}$ & 1 & - & - & 2 & 30 \\
\hline
\end{tabular}

\section{CONCLUSION AND RECOMMENDATION}

\subsection{Conclusion}

From the results of the planning and calculations above, it can be concluded as follows 
1. 1 Planning a rice dryer with a tray dryer system is an application of conventional drying which is based on drying under the sun.

2. With temperature $40{ }^{\circ} \mathrm{c}$, air speed $4 \mathrm{~m} / \mathrm{det}$, and a flow rate of hot air of $26733,615 \mathrm{~m}^{3} /$ hour and a humidity of $0,0379 \mathrm{~kg}$ water $/ \mathrm{kg}$ air is enough to dry $1000 \mathrm{~kg}$ of rice for 3,36 hours

\subsection{Recommendation}

1. To get maximum results in the drying process, it is recommended that the capacity of grain that is accommodated by the inlet dryer does not exceed the capacity

2. The construction of this dryer can be used for other agricultural products, but the calculation of heat transfer must be calculated according to the characteristics of the material to be dried.

\section{REFERENCES}

1. AAK. Budi daya Tanaman Padi, Kanesius, 13, 2006.

2. Anggraini, L., Tanaka, B., Matsuzuka, N., Isono, Y., Japanese Journal of Applied Physics, 52(5R), 2013.

3. Benhard D. Wood, Sulkifli Harahap, Penerapan Termodnamika, Erlangga, 2, 1998.

4. Djoksetyardjo, Ketel Uap, Pradya Paramita, 4, 1999.

5. Anggraini, L., Natsume, Y. and Ameyama, K., Materials Science Forum, Trans Tech Publications Ltd., 864, 2016.

6. Geankopolis, Cristie. J, Taransport Processes and Unit Operation, Erlangga,3 1999.

7. Anggraini, L., Sugeng, IOP Conference Series: Materials Science and Engineering, IOP Publishing, 367, 2018.

8. Holman, JP. Prinsip Perpindahan Kalor, Erlangga, 1995.

9. Anggraini, L., Yamamoto, R., Fujiwara, H., Ameyama, K.,. Journal of Ceramic Science and Technology, 2(3), 2011.

10. Krreith, Frank, Priyono Arki, Prisnsip-prinsip Perpindahan Panas, Erlangga, 3, 1999.

11. Michael M. Howard N, Thermodinamika Teknik I , Erlangga, 4, 2004. 